\title{
Optimalisasi Fungsi Laboratorium IPAMelalui Kegiatan Praktikum Di SMP Negeri 4 Sinjai Timur Kabupaten Sinjai
}

\author{
${ }^{1}$ Muliana, ${ }^{2}$ Sri Wahyuni, ${ }^{3}$ Erwing \\ Universitas Muhammadiyah Bone \\ Email: $\underline{1}$ muliana8484@gmail.com, $\underline{2 \text { Alifawahyuni68@gmail.com }}{ }^{3}$ ewinkijo@gmail.com
}

\begin{abstract}
Article Info
Article history:

Article Accepted: 08 July 2021

Publication : 15 July 2021
\end{abstract}

Keywords:

Optimization, Science

laboratory functions, Practical Activities

\begin{abstract}
Abstrak
This study aims to determine the optimization of the science laboratory function through practical activities for class VIII students of SMP Negeri 4 Sinjai Timur, Sinjai Regency. The type of research used in this research is descriptive qualitative research which will describe the results of measurements on the optimization of the functions of the science laboratory through practicum. The population of this study were all students of class VIII A of SMP Negeri 4 Sinjai Timur, Sinjai Regency, totaling 31 people with a distribution of 11 males and 20 females. The research instruments used were questionnaires, observations and document studies. The data obtained were then analyzed using data processing and data analysis. Based on data analysis that research on how to optimize the function of the science laboratory through student practicum activities, it was concluded that the implementation aspect of biology practicum learning showed that on average each questionnaire item given to students gave an answer category above 50\% with categories strongly agree and agree and at aspects of laboratory utilization based on the questionnaires that researchers have distributed regarding optimizing the functions of the science laboratory through practical activities for class VIII students of SMP Negeri 4 Sinjai Timur on average give answers strongly agree and agree with a percentage above $50 \%$.
\end{abstract}

This is an open access article under the Lisensi Creative Commons AtribusiBerbagiSerupa 4.0 Internasional (c) (i) (2)

Corresponding Author:

${ }^{1}$ Muliana,

Universitas Muhammadiyah Bone

Email:muliana8484@gmail.com

\section{PENDAHULUAN}

Laboratorium merupakan salah satu unsur penting dalam mendukung kegiatan belajar mengajar di sekolah, khususnya untuk bidang ilmu pengetahuan alam (fisika, biologi, dan kimia) yang menuntut adanya pembuktian antara teori yang didapatkan dengan realita yang sebenarnya. Dalam kegiatan pembelajaran berdasarkan inkuiri siswa dilatih untuk mengembangkan keterampilan ilmiah, misalnya mengamati, mengumpulkan data, mengajukan peryataan, menyusun hipotesis, merancang eksperimen, maupun menarik kesimpulan. Ini berarti pembelajaran sains tidak dapat dipisahkan dengan kerja praktek.

Laboratorium merupakan sumber belajar yang efektif untuk mencapai kompetensi yang diharapkan bagi siswa. Sesuai dengan karakteristik pembelajaran IPA di sekolah yang mengutamakan kerja ilmiah sehingga siswa dapat bersikap ilmiah dan selanjutnya konsep yang telah dikuasai akan diterapkan dalam usaha pemenuhan kebutuhan hidup. Tuntutan pembelajaran IPA tidak mungkin dapat terpenuhi apabila tidak didukung oleh kemampuan guru dalam 
menyelenggarakan kegiatan praktikum di laboratorium sebagai kunci keberhasilan pembelajaran IPA.

Optimalisasi fungsi atau pemanfaatan alat di laboratorium IPA yang maksimal dapat menunjang kegiatan praktikum peserta didik dengan baik. Pemanfaatan alat di laboratorium IPA mengandung beberapa aspek, diantaranya adalah pemahaman siswa dalam menggunakan alat praktikum, rasional ketersediaan alat praktikum dengan jumlah peserta didik, serta pelaksanaan prosedur yang benar terkait penggunaan alat praktikum. Jumlah alat yang tersedia di laboratorium perlu diperhatikan pula untuk memudahkan peserta didik dalam melaksanakan kegiatan praktikum sehingga diharapkan peserta didik dapat memahami materi pembelajaran secara optimal.

Sarana pendidikan merupakan alat yang digunakan untuk menunjang proses pembelajaran di sekolah. Sarana dan prasarana memiliki klasifikasi masing-masing terhadap jenis, fungsi, dan sifatnya. Emha, (2012) menjelaskan bahwa sarana pendidikan berdasarkan fungsinya dibedakan menjadi tiga macam yakni alat pelajaran, alat peraga, dan media pengajaran.

\section{KAJIAN PUSTAKA}

\subsection{Pengertian Laboratorium}

Laboratorium (disingkat lab) adalah tempat riset ilmiah, eksperimen pengukuran ataupun pelatihan ilmiah dilakukan. Laboratorium biasanya dibuat untuk memungkinkan dilakukannya kegiatan-kegiatan tersebut secara terkendali. Sementara menurut Emha (2012), laboratorium diartikan sebagai suatu tempat untuk mengadakan percobaan, penyelidikan, dan sebagainya yang berhubungan dengan ilmu fisika, kimia, dan biologi atau bidang ilmu lain. Pengertian lain dari laboratorium ialah suatu tempat dimana dilakukan kegiatan kerja untuk menghasilkan sesuatu. Tempat ini dapat merupakan suatu ruangan tertutup, kamar, atau ruangan terbuka, misalnya kebun dan lain-lain.

\subsection{Fungsi Laboratorium IPA}

Sekolah Menengah Pertama seharusnya memiliki laboratorium IPA yang terdiri dari laboratorium kimia, fisika, dan biologi. Rumini Sri (2011) memaparkan bahwa laboratorium mempunyai fungsi mempersiapkan sarana penunjang untuk melaksanakan pendidikan dan pengajaran dalam satu bidang studi dan mempersiapkan sarana penunjang untuk melaksanakan penelitian dalam satu bidang studi. Menurut Richard (2013:116), fungsi laboratorium IPA adalah sebagai berikut:

1) Memperkuat pemahaman tentang konsep IPA, baik bagi siswa (peserta penelitian di laboratorium IPA) ataupun bagi guru IPA

2) Menumbuhkan minat, inspirasi, motivasi, dan percaya diri dalam mempelajari IPA

3) Memperkuat daya imajinasi siswa dan seluruh individu yang terlibat dalam kegiatan di laboratorium IPA, memicu inspirasi, serta dapat mengembangkan kreativitas para peserta dalam melakukan eksperimen mengenai materi-materi pelajaran IPA

4) Melatih keterampilan eksperimen

5) Mengembangkan kemampuan para peneliti untuk membuat judgment (keputusan) dalam pengujian teori ataupun eksperimentasi

6) Wadah memperbaiki pendapat atau pemahaman yang salah atau miskonsepsi tentang peajaran atau teori-teori yang ada dalam IPA

7) Wahana bagi peserta atau siswa untuk menciptakan sikap ilmiah seperti para ahli sains, khususnya dalam hal materi IPA

8) Para siswa atau peserta akan memperoleh kejelasan konsep, dan visualisasi konsep

9) Sebagai media untuk menumbuhkan nalar kritis terhadap para siswa di sekolah agar mereka mampu bernalar dan berpikir secara ilmiah, sehingga mereka akan menjadi calon-calon ilmuwan dunia. 


\section{METODE PENELITIAN}

\section{a. Jenis Penelitian}

Menurut Sarwono (2013:14-15) mendefinisikan metode penelitian kuantitatif merupakan metode penelitian yang berlandaskan pada filsafat positivisme, digunakan untuk meneliti pada populasi atau sampel tertentu.

\section{b. Instrumen Penelitian}

Instrumen dalam penelitian adalah alat atau fasilitas yang digunakan peneliti dalam mengumpulkan data agar pekerjaannya lebih mudah dan hasilnya lebih baik, dalam arti lebih cermat, lengkap dan sistematis sehingga lebih mudah diolah. Adapun instrumen yang digunakan pada penelitian ini adalah sebagai berikut:

1. Lembar Angket

Menurut Martinis (2016: 128), menyatakan, “Angket atau kuesioner adalah sejumlah peryataan atau peryataan yang digunakan untuk memperoleh informasi sampel dalam arti laporan pribadinya, atau hal-hal yang ia ketahui."

2. Lembar Observasi

Observasi diartikan sebagai kegiatan mengamati secara langsung, tanpa mediator untuk melihat dengan dekat kegiatan yang dilakukan objek tersebut. Observasi merupakan salah satu teknik pengumpulan data dengan cara melakukan pengamatan langsung terhadap objek yang akan diteliti (Muhammad Idrus, 2009).

3. Studi dokumen

Menurut Jonathan Sarwonno (2013: 225) menjelaskan studi dokumentasi merupakan sarana pembantu peneliti dalam mengumpulkan data atau informasi dengan cara membaca surat-surat, pengumuman, iktisar rapat, pernyataan tertulis kebijakan tertentu dan bahanbahan tulisan lainnya.

\section{c. Teknik Pengumpulan Data}

Metode pengumpulan data merupakan cara yang dilakukan peneliti untuk mengungkap atau menjaring informasi kuantitatif dari responden sesuai lingkup penelitian. Adapun metode pengumpulan data yang digunakan dalam penelitian ini, antara lain:

1. Angket

Angket dalam penelitian ini merupakan teknik pengumpulan data yang dilakukan dengan cara memberi seperangkat peryataan atau peryataan tertulis kepada responden untuk

dijawabnya.

2. Observasi

Pengumpulan data dalam penelitian ini menggunakan teknik observasi tidak terstruktur, yaitu peneliti tidak menggunakan instrumen yang telah baku tetapi hanya rambu-rambu pengamatan.

3. Studi dokumen

Dalam penelitian ini dokumen yang dapat dijadikan sebagai tambahan informasi antara lain: daftar inventaris laboratorium IPA, jadwal praktikum, prosedur/modul praktikum, LKS praktikum, dan tata tertib laboratorium IPA.

\section{d. Teknik Analisis Data}

Menurut Sopiatin (2013: 1207), analisis data merupakan kegiatan setelah data dari seluruh responden atau sumber data lain terkumpul. Data yang telah diperoleh terlebih dahulu dianalisa agar dapat dipergunakan untuk menjawab rumusan masalah yang ditetapkan.

Dalam penelitian ini skor tertibggi dalam angket yaitu 5, dan skor terendah nya yaitu 1. Dari data yang telah dirubah persentase tersebut kemudian dianalisis dalam kategori kualitatif. Sebagai acuan kategori kualitatif ditetapkan kriteria dengan cara membagi rentangan jarak pengukuran. 


\subsection{HASIL PENELITIAN DAN PEMBAHASAN}

\subsubsection{Hasil Penelitian}

\section{a. Gambaran Angket pada Aspek Pemanfaatan Laboratorium}

Untuk melihat gambaran angket pada aspek pemanfaatan laboratorium SMP Negeri 4 Sinjai Timur Kabupaten Sinjai dalam hal ini sesuai dengan hasil penelitian penulis, sebagaimana yang diungkapkan dalam bentuk tabel berdasarkan data angket yang diedarkan pada responden.

\section{b. Pembahasan}

Penelitian ini bertujuan untuk mengetahui optimalisasi fungsi laboratorium IPA melalui kegiatan praktikum siswa kelas VIII SMP Negeri 4 Sinjai Timur. Menurut Sugiyono (2013:1415) mendefinisikan bahwa metode penelitian kuantitatif merupakan metode penelitian yang berlandaskan pada filsafat positivisme, digunakan untuk meneliti pada populasi atau sampel tertentu. Penelitian deskriptif kualitatif adalah penelitian yang menggambarkan atau melukiskan objek penelitian berdasarkan fakta-fakta yang tampak atau sebagaimana mestinya. Penelitian ini merupakan penelitian deskriptif kualitatif yang akan memaparkan hasil pengukuran tentang Optimalisasi Fungsi laboratorium IPA melalui Praktikum Siswa Kelas VIII SMP Negeri 4 Sinjai Timur. Data pada hasil penelitian ini selanjutnya dijabarkan secara rinci, terdiri dari 2 aspek yang menjadi titik fokus penelitian yaitu (1) Aspek Keterlaksanaan Pembelajaran Praktikum Biologi dan (2) Aspek Pemanfaatan Laboratorium.

1. Aspek Keterlaksanaan Pembelajaran Praktikum Biologi

Dalam penelitian ini ada dua spek yang menjadi fokus penelitian salah satu diantaranya yaitu pada aspek keterlaksanaan pembelajaran praktikum biologi dari 10 angket yang disebar kepada tiap responden dapat diuriakan mulai dari angket nomor 1 dimana angket tersebut berbunyi "saya senang dengan mata pelajaran biologi terutama ketika praktikum dilaboratorium" berdasarkan hasil yang diperoleh bahwa dari 31 orang siswa 20 orang siswa menjawab pada kategori sangat setuju dengan persentase $64,5 \%, 11$ orang siswa menjawab pada kategori setuju dengan persentase 35,5\%, angket nomor 2 dengan peryataan "saya berpartisipasi aktif dalam kegiatan praktikum di laboratorium" bisa dikatakan setuju", dari 31 orang siswa 17 orang siswa menjawab pada kategori sangat setuju dengan persentase 54,8\%, 12 orang siswa menjawab pada kategori setuju dengan persentase 38,7\%, 2 orang siswa menjawab pada kategori ragu-ragu dengan persentase $6,5 \%$, jawaban bervariasi tersebut dapat diartikan bahwa hampir semua siswa berpartisipasi aktif dalam kegiatan praktikum di laboratorium, angket nomor 3 dengan pernyataan bahwa "saya senang dengan kegiatan praktikum biologi di sekolah", dari 31 orang siswa 19 orang siswa menjawab pada kategori sangat setuju dengan persentase $61,3 \%, 12$ orang siswa menjawab pada kategori setuju dengan persentase $38,7 \%$, jawaban tersebut dapat diartikan bahwa siswa senang dengan kegiatan praktikum biologi di sekolah.

Selanjutnya angket nomor 4 dengan pernyataan bahwa "saya antusias mengikuti kegiatan praktikum biologi dilaboratorium", dari 31 orang siswa 23 orang siswa menjawab pada kategori sangat setuju dengan persentase $74,2 \%, 6$ orang siswa menjawab pada kategori setuju dengan persentase 19,4\%, 2 orang siswa menjawab pada kategori setuju dengan persentase $6,5 \%$, jawaban tersebut dapat diartikan bahwa antusias mengikuti kegiatan praktikum biologi dilaboratorium, angket nomor 5 dengan pernyataan bahwa "saya senang cara penyampaian materi biologi praktek dilaboratotium dibandingkan dengan dikelas" dari 31 orang siswa 22 orang siswa menjawab pada kategori sangat setuju dengan persentase $71,0 \%, 7$ orang siswa menjawab pada kategori setuju dengan persentase $22,6 \%, 2$ orang siswa menjawab pada kategori setuju dengan persentase $6,5 \%$, angket nomor 6 dengan pernyataan bahwa "saya memanfaatkan alat dan bahan praktikum secara optimal" dari 31 orang siswa 17 orang siswa menjawab pada kategori sangat setuju dengan persentase $54,8 \%, 12$ orang siswa menjawab pada kategori setuju dengan persentase 38,7\%, 2 orang 
siswa menjawab pada kategori setuju dengan persentase 6,5\%, angket nomor 7 dengan pernyataan bahwa "saya selalu mentaati tata tertib setiap melaksanakan praktikum dilaboratorium" dari 31 orang siswa 20 orang siswa menjawab pada kategori sangat setuju dengan persentase $64,5 \%, 11$ orang siswa menjawab pada kategori setuju dengan persentase $35,5 \%$, jawaban tersebut dapat diartikan bahwa semua siswa sangat setuju dan setuju dengan tata tertib setiap melaksanakan praktikum dilaboratorium.

Selanjutnya untuk angket nomor 8 dengan peryataan "saya bertanggung jawab atas alat-alat yang saya gunakan untuk praktikum" dari 31 orang siswa 15 orang siswa menjawab pada kategori sangat setuju dengan persentase 48,4\%, 10 orang siswa menjawab pada kategori setuju dengan persentase 32,3\%, 6 orang siswa menjawab pada kategori ragu-ragu dengan persentase $19,4 \%$, hal ini menunjukan bahwa siswa bertanggung jawab atas alat-alat yang mereka gunakan pada saat praktikum pada angket nomor 9 dengan peryataan "saya lebih senang belajar biologi dilaboratorium" dari 31 orang siswa 22 orang siswa menjawab pada kategori sangat setuju dengan persentase $71,0 \%, 9$ orang siswa menjawab pada kategori setuju dengan persentase $29,0 \%$, hal ini menujukkan bahwa siswa sangat senang belajar biologi dilaboratorium, selanjutnya untuk angket terakhir pada aspek keterlaksanaan pembelajaran praktikum biologi angket nomor terakhir yaitu nomor 10 dengan peryataan "saya selalu bertanya kepada guru ketika kesulitan dalam praktikum dilaboratorium" dari 31 orang siswa 17 orang siswa menjawab pada kategori sangat setuju dengan persentase 54,8\%, 12 orang siswa menjawab pada kategori setuju dengan persentase 38,7\%, 2 orang siswa menjawab pada kategori ragu-ragu dengan persentase $19,4 \%$ hal ini menujukkan bahwa siswa selalu bertanya kepada guru ketika kesulitan dalam praktikum dilaboratorium, ini menunjukkan atau sejalan dengan pernyataan angket sebelum-sebelumnya bahwa rasa senang siswa belajar paraktikum dilaboratorium memang cukup disetuji oleh siswa.

\section{c. Gambaran pada Aspek Pemanfaatan Laboratorium}

Berdasarkan angket yang telah peneliti sebarkan kepada tiap responden mengenai optimalisasi fungsi laboratorium IPA melalui kegiatan praktikum siswa kelas VIII SMP Negeri 4 Sinjai Timur pada aspek pemanfaatan laboratorium dengan jumlah angket pada aspek ini sama dengan aspek sebelumnya yaitu berjumlah 10 nomor dengan kategori jawaban sangat setuju, setuju, ragu-ragu, tidak setuju dan sangat tidak setuju. Untuk angket nomor 1 dengan peryataan "laboratorium di sekolah memiliki alat-alat praktikum yang memadai" dari 31 orang siswa 17 orang siswa menjawab pada kategori sangat setuju dengan persentase 54,9\%, 13 orang siswa menjawab pada kategori setuju dengan persentase 41,9\%, 1 orang siswa menjawab pada kategori ragu-ragu dengan persentase 3,2\% hal tersebut menunjukkan bahwa laboratorium di sekolah memiliki alat-alat praktikum yang memadai, untuk angket nomor 2 dengan peryataan "setelah praktikum biologi tidak perlu membuat laporan praktikum karena hanya bersifat pembuktian teori yang sudah ada" dari 31 orang siswa 16 orang siswa menjawab pada kategori sangat setuju dengan persentase $51,6 \%, 12$ orang siswa menjawab pada kategori setuju dengan persentase $38,7 \%, 3$ orang siswa menjawab pada kategori ragu-ragu dengan persentase 9,7\%, untuk angket nomor 3 dengan peryataan "saya membersihkan peralatan setiap selesai melaksanakan praktikum di laboratorium" dari 31 orang siswa 18 orang siswa menjawab pada kategori sangat setuju dengan persentase $58,1 \%, 13$ orang siswa menjawab pada kategori setuju dengan persentase $41,9 \%$, dan selanjutnya.

Selanjutnya untuk angket nomor 4 dengan peryataan "pembelajaran biologi di kelas dengan latihan soal lebih mudah dipahami" dari 31 orang siswa 18 orang siswa menjawab pada kategori sangat setuju dengan persentase $58,1 \%, 9$ orang siswa menjawab pada kategori setuju dengan persentase $29,0 \%, 4$ orang siswa menjawab pada kategori setuju dengan persentase 12,9\%, hal ini menunjukkan bahwa pembelajaran biologi di kelas dengan latihan soal lebih mudah dipahami oleh siswa terlihat dari kategori jawaban yang diberikan 
siswa, untuk angket nomor 5 dengan peryataan "praktikum biologi menambah minat belajar saya" dari 31 orang siswa 17 orang siswa menjawab pada kategori sangat setuju dengan persentase $54,8 \%, 13$ orang siswa menjawab pada kategori setuju dengan persentase 41,9\%, 1 orang siswa menjawab pada kategori setuju dengan persentase $3,2 \%$, untuk angket nomor 6 dengan peryataan "guru sering melaksanakan praktikum pada materi biologi" dari 31 orang siswa 18 orang siswa menjawab pada kategori sangat setuju dengan persentase $54,8 \%$, 13 orang siswa menjawab pada kategori setuju dengan persentase $41,9 \%$.

Selanjutnya pada angket nomor 7 dengan peryataan "di sekolah harus memiliki laboratorium yang lengkap" dari 31 orang siswa 16 orang siswa menjawab pada kategori sangat setuju dengan persentase $51,6 \%, 13$ orang siswa menjawab pada kategori setuju dengan persentase 41,9\%, 2 orang siswa menjawab pada kategori setuju dengan persentase $6,5 \%$, angket nomor 8 dengan peryataan "melakukan eksperimen di laboratorium sangat bermanfaat karena dapat melatih keterampilan saya dalam menggunakan alat-alat laboratorium" dari 31 orang siswa 21 orang siswa menjawab pada kategori sangat setuju dengan persentase $67,7 \%, 10$ orang siswa menjawab pada kategori setuju dengan persentase $32,3 \%$, angket nomor 9 dengan peryataan bahwa "melakukan eksperimen di laboratorium sangat bermanfaat karena dapat melatih rasa tanggung jawab" dari 31 orang siswa 18 orang siswa menjawab pada kategori sangat setuju dengan persentase 58,1\%, 9 orang siswa menjawab pada kategori setuju dengan persentase $29,0 \%, 4$ orang siswa menjawab pada kategori setuju dengan persentase $12,9 \%$.

Selanjutnya untuk angket terakhir yaitu pada angket nomor 10 dengan peryataan "pembelajaran dengan kegiatan praktikum dapat menumbuhkan sikap ilmiah dalam diri saya, dari 31 orang siswa 17 orang siswa menjawab pada kategori sangat setuju dengan persentase $54,8 \%, 13$ orang siswa menjawab pada kategori setuju dengan persentase $41,9 \%$, 1 orang siswa menjawab pada kategori setuju dengan persentase 3,2\%, hal tersebut menujukkan bahwa pembelajaran dengan kegiatan praktikum dapat menumbuhkan sikap ilmiah dalam diri siswa. Berdasarkan dari hasil angket yang telah diberikan siswa mengenai optimalisasi fungsi laboratorium IPA melalui kegiatan praktikum siswa kelas VIII SMP Negeri 4 Sinjai Timur khusus pada aspek pemanfaatan pembelajaran praktikum rata-rata dari semua item angket pernyataan menjawab pada kategori jawaban sangat setuju dan setuju mengenai optimalisasi fungsi laboratorium IPA melalui kegiatan praktikum siswa.

\section{SIMPULAN}

Berdasarkan penelitian mengenai bagaimana optimalisasi fungsi laboratorium IPA melalui kegiatan praktikum siswa kelas VIII SMP Negeri 4 Sinjai Timur, maka diperoleh kesimpulan:

1. Pada aspek keterlaksanaan pembelajaran praktikum biologi. Berdasarkan penelitian mengenai bagaimana optimalisasi fungsi laboratorium IPA melalui kegiatan praktikum siswa diperoleh kesimpulan pada aspek keterlaksanaan pembelajaran praktikum biologi menunjukkan bahwa rata-rata tiap butir angket yang diberikan kepada siswa memberikan kategori jawaban diatas 50\% dengan kategori sangat setuju dan setuju termasuk butir angket dengan pernyataan saya senang dengan mata pelajaran biologi terutama ketika praktikum dilaboratorium" dari 31 orang siswa 20 orang siswa dengan persentase $64,5 \%$ dan 11 orang siswa dengan persentase $35,5 \%$, dan untuk angket dengan pernyataan selalu mentaati tata tertib setiap melaksanakan praktikum dilaboratorium dari 31 orang siswa 20 orang siswa dengan persentase 64,5\%, 11 orang siswa dengan persentase $35,5 \%$, dengan kategori jawaban sangat setuju dan setuju dan selanjutnya untuk angket dengan pernyataan siswa lebih senang belajar biologi dilaboratorium" dari 31 orang siswa 22 orang siswa dengan persentase $71,0 \%, 9$ orang siswa dengan persentase $29,0 \%$ dengan kategori jawaban sangat setuju dan setuju hal ini menujukkan bahwa fungsi laboratorium IPA melalui kegiatan praktikum siswa kelas VIII SMP Negeri 4 Sinjai Timur perlu di optimalkan lebih maksimal lagi dari sebelumnya. 
2. Pada aspek pemanfaatan laboratorium berdasarkan angket yang telah peneliti sebarkan mengenai optimalisasi fungsi laboratorium IPA melalui kegiatan praktikum siswa kelas VIII SMP Negeri 4 Sinjai Timur yang berjumlah 10 nomor pada angket dengan peryataan "siswa membersihkan peralatan setiap selesai melaksanakan praktikum di laboratorium" dari 31 orang siswa 18 orang siswa menjawab sangat setuju dengan persentase $58,1 \%, 13$ orang siswa menjawab setuju dengan persentase $41,9 \%$, pada angket dengan peryataan "guru sering melaksanakan praktikum pada materi biologi" dari 31 orang siswa 18 orang siswa menjawab sangat setuju dengan persentase $54,8 \%, 13$ orang siswa menjawab setuju dengan persentase $41,9 \%$ dan selanjutnya untuk angket nomor 8 dengan peryataan "melakukan eksperimen di laboratorium sangat bermanfaat karena dapat melatih keterampilan saya dalam menggunakan alat-alat laboratorium" dari 31 orang siswa 21 orang siswa menjawab sangat setuju dengan persentase 67,7\%, 10 orang siswa menjawab setuju dengan persentase 32,3\%. Berdasarkan dari hasil angket yang telah diberikan siswa mengenai optimalisasi fungsi laboratorium IPA melalui kegiatan praktikum siswa kelas VIII SMP Negeri 4 Sinjai Timur khusus pada aspek pemanfaatan pembelajaran praktikum rata-rata dari semua item angket pernyataan menjawab pada kategori jawaban sangat setuju dan setuju yang berartif fungsi laboratorim harus lebih diperhatikan demi tercapainya pembelajaran yang maksimal terutama pada pelaksanaan praktikum dilaboratorium.

\section{SARAN}

Berdasarkan hasil penelitian bagaimana optimalisasi fungsi laboratorium IPA melalui kegiatan praktikum siswa kelas VIII SMP Negeri 4 Sinjai Timur, ada beberapa hal yang dapat dijadikan saran, diantaranya adalah sebagai berikut:

3. Sebaiknya pengelola laboratorium IPA di SMP Negeri 4 Sinjai Timur memberlakukan kebijakan praktikum sesuai dengan kepentingan siswa dalam hal materi pelajaran yang harus dipraktikumkan lebih mendapat perhatian dari guru dan pengelola.

4. Sebaiknya pengelola laboratorium IPA di SMP Negeri 4 Sinjai Timur menyiapkan modul praktikum tiap siswa dari seluruh materi pelajaran yang dipraktikumkan, agar seluruh materi yang dipraktikumkan serta hasil praktikum terkumpul menjadi satu modul yang mudah untuk dipelajari siswa hal ini dimaksudkan untuk memaksimalakn fungsi laboratorium.

\section{DAFTAR PUSTAKA}

Emha, 2012. Efektiftas Penggunaan Laboratorium Dalam Menunjang Pembelajaran Siswa. (Online): Diakses 25 Januari 2019

Martinis Yamin, 2016. Pembelajaran Di Laboratorium. Yogyakarta Pusat Pendidikan Pengembangan Pendidikan Universitas Gajah Mada

Mulyasa. 2009. Manajemen Berbasis Sekolah. Bandung: Remaja Rosdakarya Offset

Richard, 2013. Analisis Pengelolaan Laboratorium. Jakarta: Kencana.

Sarwonno, 2013. Metode Penelitian Survei. Jakarta: LP3ES:

Sopiatin, 2013. Kontribusi Pengelolaan Laboratoriun Terhadap Motivasi Belajar Siswa. Online:

Diakses 20 Januari 2019

Sri Rumini, 2011. Mendesain Model Pembelajaran Inovatif-Progesif. Jakarta: Kencana.

Tim Instruktur Diklat Kepala Laboratorium, 2012: 24.

Usman, 2011. Model Desain Sistem Pembelajaran. Jakarta: Dian Rakyat

Winataputra, 2010. Strategi Pembelajaran. Bandung: PT. Remaja Rosdakarya Offset. 